\title{
The Implementation of Agricultural Products Agreements In Cina Subdistrict of Bone District (Socio-Juridical Review)
}

\author{
Bakhtiar* \\ Departemen of Pancasila and Civic \\ Education \\ Faculty of Social Science \\ Universitas Negeri Makassar \\ Makassar, Indonesia \\ bakhtiar@unm.ac.id
}

\author{
Muh. Said \\ Departemen of Social Science \\ Education \\ Faculty of Social Science \\ Universitas Negeri Makassar \\ Makassar, Indonesia \\ muh.said@unm.ac.id
}

\author{
Muh. Rizal \\ Departemen of Bussines \\ Administration \\ Faculty of Social Science \\ Universitas Negeri Makassar \\ Makassar, Indonesia \\ muh.rizal@unm.ac.id
}

\begin{abstract}
The implementation of the agricultural production sharing agreement sholud be in accord with Regulation No. 2, 1960, but in the reality this regulation is not obeyed by the land-owner farmers and land-tiller farmers. This research aimed at describing the implementation of the production sharing agreement, its correspondence with Regulation No. 2, 1960, the level of the community's understanding of Regulation No. 2, 1960, and the efforts taken by the competent officials so that Regulation No. 2, 1960 can be implemented effectively in Cina Subdistrict. This research was a descriptive research with the informants taken purposively from land-owner farmers and land-tiller farmers whose number was 10 persons respectively, the head of Awo Village, the head of Kawerang Village and the head of Cina Subdistrict. The data were collected through interviews and documentation and analyzed by using descriptive-qualitative analysis. The results of the research showed that the implementation of the agricultural production sharing agreement is based on the customs that have taken place from generation to generation; the implementation of the agricultural production sharing agreement is not in accord with Regulation No. 2, 1960; and the government officials, at Subdistrict level as well as at Village level, have never carried out the socialization of Regulation No. 2, 1960 to the community of farmers in Cina Subdistrict of Bone District.
\end{abstract}

Keywords: Agreement, Sharing production, Agricultural

\section{INTRODUCTION}

The opening of the 1945 Constitution, the fourth Paragraph affirms the state of Indonesia aims to: "... protect all Indonesians and all Indonesian spills, promote public welfare ..." To make this happen, the state institutions are authorized to establish and implement the policy.

The mastery and utilization of land in various forms and terms, can be said not to be new in this country. All phenomena concerning land are governed by land law. The government has been working so that the interests in this field of land can be realized for the public good. One of them is the issue of national legal products, namely Law No. 2 of 1960 on The Agreement on The Share of Agricultural Land Products.

As a follow-up, the government has issued Presidential Instruction No. $13 / 1980$ on the guidelines for implementation of Law No. 2 of 1960 on the agreement for the share of agricultural land products, in hopes of facilitating Law No. 2 of 1960 in its implementation.

In connection with the above, Harsono states that the availability of legal provisions alone cannot be itself a driver, because the law of land as a man-made law, will not apply by itself without the awareness, will, justice, and sincerity of every member of society to obey it [1].

Pointing to observations on the conduct of the community, the authors found indications that the practice of administering the provisions of the Income-Share Act in the Chinese District of Bone Regency had not been realized properly. People still refer to customs that have been considered to benefit the parties.

Based on the background description, the formulation of the research problem is: (1) How is the implementation of the agreement for the share of agricultural land in the District of China Bone Regency? (2) Is its implementation in accordance with the provisions of Law No. 2 of 1960? (3) How does the public understand the provisions of Law No. 2 of 1960? and (4) What efforts are made by the authorities so that the provisions of Law No. 2 of 1960 can be implemented effectively?

The objectives to be achieved in the implementation of this research are as follows: (1) To obtain an overview of the implementation of the agreement for the share of agricultural land. (2) compliance with the implementation of the agricultural land share agreement with the provisions of Law No. 2 of 1960. (3) public understanding of the provisions of Law No. 2 of 1960, and (4) what efforts are made by the authorities so that the provisions of Law No. 2 of 1960 can be implemented effectively.

Benefits that can be obtained, among others are: (1) adding and expanding scientific thinking insights. (2) provide an understanding of the importance of knowing the provisions of the results-share Law as one of the products of law held to create order in society. (3) may further enforce the provisions of the results-share Law so that its implementation can be implemented effectively. (4) reference materials, especially in the development of Science.

In the English General Dictionary Poerwadarminta,it is mentioned that the terms of the agreement mean consent (written or oral) made by two or more parties, each promising to abide by what is in that agreement [2].

Prodjodikoro states that the agreement is a legal relationship concerning property between two parties, in which party promises or is deemed to promise to do something in accordance with the agreement, while the other party has the right to demand the implementation of the promise or content of the agreement [3].

Subekti says that: "A covenant is a bond in which one promises another person or where two people promise each other to do something[4]." 
Article 1313 of the Civil Code, it is stated that the intended agreement is: "An act by which one or more person binds himself or herself to one or more others."

Parlindungan states the various terms of the profitshare agreement are as follows: "Maro or Mertelu in Central java and East Java, Nengah or Jejuron for west Java, in Lombok called Nyakap, in Minahasa with the term Toyo and in South Sulawesi known as Teseng or Tesang [5]."

Ter Haar suggested that in indigenous peoples, land has a very important position in a community. The importance of land position for indigenous peoples is due to some things concerning their view of the land, namely: (1) is the residence of the alliance; (2) give life to the fellowship; (3) is the place where the citizens of the deceased are interred; and (4) is also the dwelling place of the protectors of communion and the spirits of the fathers [6].

Yusuf suggested that the social function of the land in indigenous peoples in our country appears in the custom of the owner to allow his fellow citizens at certain times to use his property, for example allowing to herd his cattle on his rice fields freely, which means giving the possibility of his neighbors also weaning or enjoying the results [7].

In the agreement for the share of rice fields (teseng), there are terms that can distinguish between the person who owns the land (the owner) and the owner. From the term teseng above, to be able to distinguish between the owner and the owner is used the term patteseng on behalf of the owner of the rice field, while for the person who works is known by the term atteseng. It is between patteseng and atteseng who enter into this agreement that the saelanjutnya called teseng or the agreement of the results.

Furthermore, to avoid misinterpretation both on the part of the community and from the law enforcement itself, in the explanation article after article among others it is explained that the agreement of land business with the share of the name is not the same in all regions. In Minangkabau, for example, it is called customize, in Minahasa; toyo, in Central java and East Java; maro or martelu, in Priangan; negah or jejuroh, in Lombok; the landscape." And allah is all-employed, all-10. The workarap, as is the case with the owner, can also be a legal entity.

By looking at the provisions in the results-making Law, it can be argued that the expiration of the yield-share agreement is due to: (1) The expiration of the promised period, (2) the owner of the rice field dies, (3) the claiming party does not work the land as it should or does not work, and (4) neither the owner nor the landowner fulfills the specified obligations.

Mertokusumo suggests that legal awareness often arises from real events or events [8]. Sudirman suggested that factors affecting public legal awareness consist of (1) internal factors, including knowledge, understanding, attitude, and legal behavior of a person, and (2) external factors, among others caretaker factors with laws, superiors with subordinates, authority and teachings, the public environment with its influence [9].

Other factors that can influence public legal awareness as stated by Chaeruddin include (1) administrative mechanisms that still need to be improved, (2) the association of living on a family basis that is still dominant in the countryside, between the community and the government, (3) the rate of population growth, and (4) political problems [10]. According to Soebagio that the legal awareness of society can be influenced by educational, geographic, and communication factors [11]

\section{RESEARCH METHODS}

This type of research is a descriptive study that intends to describe the implementation of the agreement for the hasi of agricultural land associated with the provisions of Law No. 2 of 1960 on the Agreement on The Share of Agricultural Land. The location of this research is in the jurisdiction of China District Bone Regency, precisely in villages / villages scattered within the chinese sub-district.

In this study, the study is the implementation of the agreement for the share of agricultural land. Variable is (1) Implementation of agricultural land share agreement in China District bone regency, (2) Conformity of the implementation of agricultural land-share agreement in Bone District of China District with the provisions of Law No. 2 of 1960, (3) the level of public understanding in Bone District of China District concerning the provisions of Law No. 2 of 1960, and (4) Efforts made by the authorities so that the provisions of Law No. 2 of 1960 can be implemented effectively.

The research was designed descriptively to describe the implementation of the results-share agreement, its compliance with Law No. 2 of 1960, the understanding of the peasant community about Law No. 2 of 1960, and the efforts of the authorities to socialize the provisions of Law No. 2 of 1960

In order to avoid misunderstandings and different interpretations of variables/concepts in this study, the following opersional definitions are made: (1) The implementation of the revenue-sharing agreement is an agreement made by the parties (owners and workers), regarding the form, period, manner of sharing, the remove of the agreement, and other provisions contained in Law No. 2 of 1960 concerning the revenue sharing agreement. (2) The suitability of the implementation of the revenue-sharing agreement with the provisions of Law No. 2 of 1960 is the implementation of the revenue sharing agreement in accordance with the provisions of Law No. 2 of 1960 which includes the form, period, manner of division, the dising of the agreement, and other provisions. (3) The understanding of the farmer community on the provisions of revenue sharing according to Law No. 2 of 1960 is the understanding of the peasant community in the District of China regarding the form, time frame, way of division, the dises of the agreement, and other provisions. (4) The efforts of the authorities are measures taken by the authorities namely the camat, PPL officers, and village heads / lurah introduce provisions on the agreement for the share of results according to Law No. 2 of 1960.

The research area is a village/village located within the jurisdiction of the Chinese sub-district government. Given in general the characteristics of agricultural land in China subdistrict there are two types, namely irrigated farmland and rainy farmland, then the research area is taken by two villages, one village whose farmland uses irrigation, and one village whose farmland uses rain tadah. The villages /villages that are sampled in the area include: 1 . Rain cover: (1) Tanete Village (2) Tanete Harapan Village; (3) Kawerang Village; (4) Abbumpungeng Village, (5) Arasoe Village; (6) Lompu Village; and (7) Ajangpulu Village. 2. Irrigation; (1) Awo Village; (2) Padang Loang Village; (3) Kanco Village; (4) Walenreng Village; and (5) Cinennung Village.

The research established a research area that is Kawerang Village representing the land of rain-covered agriculture, and Awo Village represents the irrigation farm that was chosen deliberately (purposive sampling).

The population in the study is an entire data source that allows providing useful information for research 
problems. A data source is a source of information in relation to obtaining data on research issues [12]. Researchers simply take a portion of the population on the terms, traits and characteristics representing the population, so that data and information obtained from a portion of that population can be used to estimate its population.

At the point of rejecting the above understanding, the data source in this study is farmers who come from villages whose farmland uses irrigation and who use rainwater, each represented by 10 informants, consisting of each of the five farmer owners and farmers, so that the respondents number 20 people, who are chosen deliberately (purpsoive sampling). While informants from the apparatus are the Chinese Camat, The Head of Awo Village, and the Head of Kawerang Village.

To facilitate the collection of data according to the desired, the techniques used in this study, are: (1) Interview, which is an activity carried out to obtain data or information by asking directly to the respondent [13]. This interview was conducted to obtain information directly from the respondent, who in this case is the owner farmer and the farmer of the farmer. In addition to the respondents, researchers also conducted interviews with the authorities. (2) Documentation, in the form of records and archives relating to the agreement for the share of agricultural land found at the research site. By recording some of the things in the documents belonging to sub-districts / villages / villages, so as to support the objectity of the interview results data.

The research instruments used are divided into two, namely: (1) Interview guidelines; to conduct interviews with farmers and farmers, as well as the authorities, concerning the implementation of the result-share agreement, compliance with Law No. 2 of 1960, the public's understanding of the provisions of Law No. 2 of 1960, and the efforts of the authorities to make the provisions of Law No. 2 of 1960. (2) Documentation notes; to obtain documentation data relating to agricultural land share agreements.

The analytical techniques used in this study are qualitative descriptive analysts. This data analysis technique is done by systematically organizing records related to the results of interviews and documentation that then present them as findings in this study. To do this activity starts with preparation, presentation of data, and conclusion making. This series of activities is carried out simultaneously and continuously.

\section{RESULTS AND DISCUSSIONS}

In the agreement for the share of agricultural land, there are terms that can distinguish between the person who owns the land (the owner) and the owner [14]. From the term pinreng above, to be able to distinguish between the owner and the owner is used the term pappinreng on behalf of the owner of the farmland, while for the person who works is known by the term mappinreng. Between pappinreng and mappinreng who entered into this agreement is the next so-called pinreng or yield-share agreement.

Regarding the period in the yield-share agreement, always follow the planting period until after the end of the harvest period and do not close the possibility of being extended again if a mutual agreement arises, as long as the owners and the owners still trust each other and do not appear feelings of mutual harm, then the agreement for the share of the yield is still implemented without any restrictions or grace period in the agreement.

In terms of determining the distribution of profitsharing balance there are three different terms, the first is bage two which is a revenue-sharing agreement in which between the owner and the owner obtain the same share of the proceeds obtained. Secondly, bage tellu is a profit-share agreement in which the owner of the farm land obtains a $1 / 3$ share and the activist gets a $2 / 3$ share of the proceeds obtained. The three bage eppa are profit-share agreements in which the owner gets a $1 / 4$ share and the owner obtains a $3 / 4$ share of the proceeds obtained.

It has become a tradition for farmers in Bone District of China District, for turi tellu, farmer owners should not choose the middle part, so only allowed to choose the left or right part. Similarly, mappia should only be done by certain people who have been considered capable of doing so.

The remove of the crop-share agreement or by the peasant community in Bone District is called ripapolei, often occurring almost every time the growing season begins, especially in Awo Village, the average farmer is queuing up waiting for each harvest to be completed.

Farmers in Awo and Kawerang villages have differences in terms of the way the agreement is owed. Farmers in Kawerang Village told me in advance that the land was ready to be taken, while in Awo Village, it will be known after the rice field starts.

Implementation of the agreement for the share of agricultural land, both in Awo Village and Kawerang Village, its motivation and spirit in accordance with the provisions of Law No. 2 Th. 1960, but formally not fulfilled; such as Law No. 2 Th. 1960 requires a written agreement and is made in front of kades and witnessed by at least two other citizens. Similarly, the time frame is affirmed in the agreement, but in practice it depends on the owner.

Implementation of the result-share agreement made by farmers in The District of China Bone Regency, there are some that are in accordance with the provisions of Law No. 2 of 1960, such as the balance of the share of the results, as well as the subject and object of the agreement for the share of the results. However, this happened by chance, in other words the parties did not know that the agreement struck by them was in accordance with the provisions of Law No. 2 of 1960. It also shows that the spirit of Law No. 2 of 1960 has been owned by the peasant community in The District of China Bone Regency.

The agreement for the share of agricultural land carried out by the parties in The District of China Bone Regency is not in accordance with the provisions of Law No. 2 of 1960. It is said to be less suitable because only two elements are equal to the result-share balance and the subject/object share. Such conformity occurs by chance, considering that none of the provisions of Law No. 2 of 1960 are known by the people in The District of China Bone Regency [15]

The farmer community in Bone District of China district only learned of the existence of the provisions of Law No. 2 of 1960 on the agreement for the share of agricultural land products at the time the author interviewed him. The ignorance of the peasant community caused them not to understand the provisions of Law No. 2 of 1960 which governs the implementation of agreements for agricultural land products.

The provisions of Law No. 2 of 1960 were never socialized by the authorities to the peasant community, because the habits that have been followed by farmers are considered good and fulfill the sense of community justice. Although there are actions of landowners who often disappoint farmers, it is widely accepted as a consequence of being a working farmer. On the other hand, there has never been a farmer complaining about the actions of the owner's farmer that is considered detrimental, so the 
government feels it is not yet time to enact the provisions of Law No. 2 of 1960.

\section{CONCLUSION}

The implementation of agricultural land agreements in The District of China Bone Regency is generally implemented in accordance with the customs that take place throughout the generations; (1) oral agreements, (2) balance of yields, generally for three for rice crops, and for four for peanut crops, (3) remove the agreement depending on the owner, (4) there is never a problem, and (5) the farmers want a legal provision from the government that can fulfill the sense of justice, especially on the part of the farmer who often feels harmed by the owner.

Implementation of the agreement for the share of agricultural land in The District of China motivation and spirit in accordance with the provisions of Law No. 2 Th. 1960, but formally not fulfilled; such as Law No. 2 Th. 1960 requires a written agreement and is made in front of kades and witnessed by at least two other citizens. Similarly the time frame is affirmed in the agreement, but in practice it depends on the owner.

The understanding of the peasant community about the provisions of Law No. 2 Th. 1960 is none at all. This is apparent from the statement of respondents who do not know about the existence of the law.

Government officials, both at the sub-district and village level, have never held a socialization on the drafting of law No. 2 Th. 1960. So far, society in general has been relatively fair and satisfactory in implementing treaties based on traditional customs (customary norms).

Based on the conclusion, the following suggestions are submitted: (1) relevant government officials should conduct counseling/socialization provisions of Law No. 2 of 1960 and law enforcement officials to effectively implement it in daily public life. (2) Farmers should consider following the provisions of Law No. 2 of 1960 in making a profit-share agreement, so that it can be anticipated the negative impact arising from the long-used agreement that is the result of the development of increasingly dynamic and complex societal life. (3) The findings of this study should be followed up, in order to obtain new data/information that can be used to assist the community in pursuing its business activities as farmers, so that the rights and obligations of the parties become firm and defensible.

\section{ACKNOWLEDGMENT}

Thanks to the Dean of the Faculty of Social Sciences who have provided financial support for this research.

\section{REFERENCES}

[1] B. Harsono, "Aspek Yuridis Pembebasan Tanah," $J$. Huk. Pembang., vol. 21, no. 2, pp. 146-159, 1991.

[2] W. J. S. Poerwadarminta, "Kamus Umum Bahasa Inggris.” Jakarta, 1996.

[3] W. Prodjodikoro, "Asas-asas Hukum Pidana di Indonesia, cet. 3," PT Eresco, Jakarta-Bandung, 1981.

[4] E. A. Farnsworth, "The past of promise: An historical introduction to contract," Columbia Law Rev., vol. 69, no. 4, pp. 576-607, 1969.

[5] A. P. Parlindungan, Komentar Atas Undang-Undang Pokok Agraria. Alumni, 1990.

[6] S. Errico and P. Claeys, "Human Rights and the Commons: Exploring Approaches to the Governance of Land and Natural Resources beyond Indigenous Peoples' Rights. The Case of Peasants," Int. J. Minor. Gr. rights, vol. 1, no. aop, pp. 1-33, 2019.

[7] D. A. Posey and G. Dutfield, Beyond intellectual property: toward traditional resource rights for indigenous peoples and local communities. IDRC, 1996.

[8] S. Mertokusumo, "Mengenal Hukum, Liberty." Yogjakarta, 1989.

[9] A. Sudirman, "Keadilan dan Kepastian Hukum"," Pedoman Rakyat, vol. 12, 1999.

[10] O. K. Chairuddin and Mahadi, Sosiologi hukum. Sinar Grafika, 1991.

[11] R. L. Soebagio, "Policy Review of the Primary and Junior Secondary Education Sub-Sectors in East Java. Educational Policy and Planning Project. A Government of Indonesia-USAID Project.," 1992.

[12] J. I. Guerrero, A. García, E. Personal, J. Luque, and C. León, "Heterogeneous data source integration for smart grid ecosystems based on metadata mining," Expert Syst. Appl., vol. 79, pp. 254-268, 2017.

[13] L. M. Koesten, E. Kacprzak, J. F. A. Tennison, and E. Simperl, "The Trials and Tribulations of Working with Structured Data: -a Study on Information Seeking Behaviour," in Proceedings of the 2017 CHI Conference on Human Factors in Computing Systems, 2017, pp. 1277-1289.

[14] J. Bański, "The consequences of changes of ownership for agricultural land use in Central European countries following the collapse of the Eastern Bloc," Land use policy, vol. 66, pp. 120-130, 2017.

[15] J.-M. Kamatali, Introduction to Rwandan Law. Routledge, 2020. 